\title{
Europe's neglect of its own future
}

\begin{abstract}
President Bill Clinton's trip to Europe last week has raised important questions about Europe's apparent indifference to the problems of Central Europe and Yugoslavia.
\end{abstract}

PRESIDENT Bill Clinton is probably still pleased with his journey to Europe last week. For one thing, he is the first US president to have visited Minsk, the capital of Belorus; history cannot take that distinction away from him. His demonstration to the Russian people on television of how even politicians can be open in their dealings with random interlocutors will also leave a lasting impression. It is less encouraging that $\mathrm{Mr}$ Yegor Gaidar, the bastion of reform in President Boris Yeltsin's government, should have resigned his cabinet post the day after Clinton left Moscow. (Luckily, Gaidar remains a member of the Russian parliament.) And the signature in Moscow of an agreement between the United States on the one hand and Russia and the Ukraine on the other that the Ukraine will transfer ex-Soviet nuclear weapons to Russia over the next decade and then benefit from a rumoured $\$ 12$ billion may yet prove a dead letter; the president of the Ukraine has yet to win the consent of his unruly parliament in Kiev and, anyway, he needs a higher price.

But surely, Clintonites will ask, the "Partnership for Peace" the president proclaimed at the meeting of the North Atlantic Treaty Organization (NATO) in Brussels last week is here to stay? Certainly, Clinton put across the notion well, so well that politicians in Warsaw, Prague, Bratislava and Budapest spoke of their pleasure at what they had been promised. Of course, they would have preferred outright membership of NATO for the sake of the explicit military guarantees that that would automatically have given them, but Clinton could offer only a modicum of military liaison and the promise of stronger links at some time in the future. In other words, the nature of the promise is far from clear.

Time passes. Five years have gone since the Berlin Wall came down and since people on both sides of it were enlivened by an extraordinary sense of hope. Peace and prosperity were to be Europe's future. So why should the states of Central Europe now be alarmed about their security? Because prosperity has proved to be cruelly elusive. The West, and Western Europe in particular, could have helped decisively to right that state of affairs by more imaginative policies, notably by enabling Central Europe to trade its way out of its immediate difficulties. But that chance was missed. Now, even the hope of peace is put in hazard by the signs that the Ukraine and Russia are dangerously unstable. It is natural that Central Europe, denied assistance on the scale that might have helped five years ago, is now clamouring for security guarantees from NATO, only to be told that it may have them at some stage in the future. That is a measure of the West's failure.

It is not too late to put things right. The obvious institution with which to start is not NATO, but the European Union (EU), now planning to enlarge itself by the accession of Austria, Finland and Sweden, but which has not yet even the sketchiest timetable for the formal membership of the Central European states. Why the delay? There are difficulties on both sides. Although the Central European states have come a long way in five years, persisting traces of the old command economies are incompatible with the single market, while the new democracies have not yet shown themselves to be constitutionally robust. In the West, the integration of Central Europe into the EU would require, under present rules, an eastward transfer of resources that would disturb the comfort (already shaken by the continuing recession) to which Western Europe believes it is entitled. But that is a poor excuse for inaction. If, after another five years, the EU discovers that Central Europe has drifted back into its old sphere of influence, it will bitterly regret the lost opportunity. Should it not have the courage to seize it now?

Ex-Yugoslavia, and Bosnia in particular, is another matter. Under pressure from France and the United States, NATO agreed last week that there may be air-strikes against aircraft and ground troops that violate negotiated agreements, which reaffirms the position reached last year - and leaves last year's objections to this course of action unchanged. Clinton was right last week to complain that Western Europe's standing has been undermined by three years of Balkan warfare, but NATO will not be the instrument of its solution. Nor can it help much if mediators from the EU and the United Nations continue their patient redrawing of the map of Bosnia to accommodate the most recent territorial gains and losses. If the EU had the wit, it would anticipate, before much more blood is shed, the political framework within which a settlement will eventually have to be reached not just in Sarajevo but in Belgrade as well.

\section{Defection from EMBL}

Italy's plan to leave the international Heidelberg laboratory should prompt reconsideration of its function.

ITALY's decision to leave the European Molecular Biology Laboratory (EMBL) is not the end of the world for the 